\title{
Pengaruh Model Pembelajaran Cooperatif Integrated Reading and Composition (CIRC) terhadap Hasil Belajar Siswa di Kelas VIII MTsN 4 Bima
}

\author{
Dewi Sartika $^{1 *}$, Siti Musyifah ${ }^{2}$, Syarifuddin $^{3}$ \\ ${ }^{1,2}$ STKIP Bima, Bima, Indonesia \\ ${ }^{3}$ IAI Muhammadiyah Bima, Bima, Indonesia \\ *Coresponding Author: tikamamaurwa@gmail.com
}

\begin{tabular}{ll}
\hline \hline Article history & Abstrak: Model pembelajaran CIRC adalah model pembelajaran \\
Dikirim: & kooperatif terpadu, membaca dan menulis. Dengan membaca \\
04-02-2022 & siswa dapat memahami soal dan kemudian dilanjutkan mencari \\
Direvisi: & solusi dari soal tersebut. Kegiatan ini diharapkan pula siswa \\
13-02-2022 & melakukannya untuk diri sendiri dan dapat membantu siswa \\
Diterima: & lainnya untuk lebih memahami pelajaran matematika. Penelitian \\
15-02-2022 & ini bertujuan untuk mengetahui pengaruh model pembelajaran \\
& CIRC terhadap hasil belajar siswa pada materi SPLDV kelas VIII \\
Key words: & MTsN 4 Bima. Jenis penelitian adalah kuantitatif dengan metode \\
\hline Model Pembelajaran; & eksperimen. Desain eksperimen dalam penelitian ini adalah Quasi \\
Cooperative Integrated & experimental design. Populasi dalam penelitian ini yaitu seluruh \\
Reading And & siswa kelas VIII MTsN 4 Bima dari kelas A sampai kelas D \\
Composition (CIRC); & sejumlah 109 siswa. Tekhnik pengambilan sampel adalah simple \\
Hasil Belajar & random sampling dan diperoleh kelas VIII A sebagai kelas \\
& eksperimen yang diajarkan menggunakan model pembelajaran \\
& CIRC dan VIII B sebagai kelas kontrol menggunakan model \\
& konvensional. Instrumen yang digunakan berupa tes uraian \\
& (essay) sebanyak 4 nomer. Tekhnik pengumpulan data dipakai \\
& soal prettes, posttest. Tekhnik analisis data penelitian ini adalah \\
& uji normalitas, homogenitas, dan hipotesis (uji-t). Berdasarkan \\
& hasil penelitian yang diperoleh dari kelas eksperimen dengan nilai \\
& rata-rata 29,464 setelah diberikan perlakuan menggunakan model \\
& CIRC maka diperoleh nilai rata-rata 73,214 sedangkan pada kelas \\
& kontrol memperoleh nilai rata-rata 27,88 dan setelah diberi \\
& perlakuan diperoleh nilai rata-rata 57,69. Dari hasil perhitungan \\
& uji t diperoleh thitung = 4,326 $>$ tabel = 1,988 dengan taraf \\
& signifikansi 5\%. Berdasarkan kriteria pengujian hipotesis Ho \\
& ditolak dan $\mathrm{H}_{\mathrm{a}}$ diterima. Sehingga ada pengaruh model \\
& pembelajaran cooperative integrated reading composition \\
& (CIRC) terhadap hasil belajar siswa pada materi sistem \\
& persamaan linear dua variabel (SPLDV). \\
\hline
\end{tabular}

\section{PENDAHULUAN}

Pendidikan memiliki peran yang sangat penting dalam kehidupan, dimana pendidikan sangat berguna dalam hal mengembangkan berbagai kemampuan dan membentuk watak manusia. Hal ini seperti amanah dalam Undang-Undang No.20 Tahun 2003 bab 1 pasal 1 ayat 1 yang disebutkan bahwa: "Pendidikan nasional berfungsi mengembangkan kemampuan dan membentuk watak serta peradaban bangsa yang bermartabat dalam rangka mencerdaskan kehidupan bangsa, bertujuan 
untuk berkembangnya potensi peserta didik agar menjadi manusia yang beriman dan bertakwa kepada Tuhan Yang Maha Esa, berahlak mulia, sehat, berilmu, cakap, kreatif, mandiri, dan menjadi warga Negara yang demokratis serta bertanggung jawab". Salah satu masalah yang dihadapi di bidang pendidikan adalah lemahnya kegiatan pembelajaran. Pembelajaran dalam kelas diarahkan pada kemampuan peserta didik untuk banyak menghafal informasi, tanpa dituntut memahami secara mendalami informasi yang ada lalu tidak untuk menghubungkannya dengan kehidupan sehari-hari.

Pendidikan merupakan kebutuhan bagi setiap orang, dimana hampir semua kecakapan berupa pengetahuan, pemahaman, keterampilan dan sikap seseorang dapat terbentuk, berubah dan berkembang karena pendidikan. Pendidikan dapat dilakukan secara formal, di mana salah satu pelajaran yang diterapkan adalah ilmu matematika. Matematika merupakan cabang ilmu pengetahuan yang memegang peranan sangat penting dalam praktik kehidupan manusia. Aplikasi matematika diperlukan hampir dalam setiap aspek kehidupan. Matematika diberikan pada setiap jenjang pendidikan formal karena matematika membekali siswa dengan kemampuan berpikir logis, analitis, sistematis, kritis dan kreatif, serta kemampuan bekerja sama. Kemampuan tersebut diperlukan agar siswa dapat memperoleh, mengelola, dan memanfaatkan informasi untuk menghadapi keadaan yang selalu berubah dan tidak pasti. Setiap melaksanakan kegiatan belajar mengajar, guru merupakan salah satu komponen penting untuk meningkatkan pemahaman siswa sehingga hasil belajar siswa pun meningkat. guru bidang studi kelas VIII bahwa hasil belajar matematika siswa kelas VIII masih jauh dari harapan. Masih banyak siswa MTsN 4 Bima kelas VIII yang Pemahaman siswa terhadap matematika masih tergolong rendah, salah satu faktor penyebabnya karena guru menggunakan metode pembelajaran yang kurang mendukung siswa dalam meningkatkan penguasaan materi yang disampaikan oleh guru.

Berdasarkan hasil observasi di MTsN 4 Bima yang di dapat dari informasi mendapatkan nilai dibawah KKM 65. Hasil wawancara dengan guru bidang studi matematika MTsN 4 Bima, rendahnya hasil belajar siswa kelas VIII disebabkan karena masih banyak siswa yang mengalami kesulitan dalam memahami konsep matematika yang diajarkan.

Berikut dicantumkan data nilai rata-rata ulangan harian untuk masing-masing pokok bahasan pada siswa kelas VIII MTsN 4 Bima masih jauh dari harapan

Tabel 1. Nilai Rata-Rata Ulangan Harian Untuk Masing-Masing Pokok Bahasan Pada Siswa Kelas VIII MTsN 4 Bima Tahun Pelajaran 2019/2020.

\begin{tabular}{cccc}
\hline \multirow{2}{*}{ Kelas } & \multicolumn{2}{c}{ Pokok Bahasan } & \multirow{2}{*}{ KKM } \\
\cline { 2 - 3 } & Aljabar & SPLDV & \\
\hline VIII & 64,5 & 62 & 65 \\
\hline
\end{tabular}

(Sumber Data: Guru Matematika kelas VIII MTsN 4 Bima).

Selain data yang ada, peneliti disini mewawancarai beberapa siswa. Menurut siswa, alasan yang menyebabkan matematika kurang disukai, yaitu: (1) Metode penyampaian guru terhadap materi yang kurang menarik (2) Matematika dianggap pelajaran yang membosankan dan menakutkan (3) Matematika juga dianggap identik dengan angka-angka padahal matematika yang dipelajari tidak terlepas dari kehidupan sehari-hari tanpa diketahui secara langsung. Permasalahan 
kehidupan sehari-hari dalam ilmu matematika digambarkan pada materi sistem persamaan linear dua variabel (SPLDV) dalam bentuk soal cerita. kesulitan dalam memahami soal cerita yang paling banyak disebabkan karena siswa kurang tahu atau kurang paham apa yang ada dalam soal, siswa kurang memahami makna setiap kalimat yang ada, kurang mampu merumuskan apa yang diketahui dan apa yang ditanyakan, kurang mampu menghubungkan secara fungsional unsur-unsur yang diketahui untuk menyelesaikan masalah dan masih ada yang tidak tahu unsur yang harus dimisalkan dalam satu atau lebih variabel sehingga hasil yang dicapai oleh siswa belum maksimal.

Berdasarkan informasi dari siswa, beberapa alternatif bisa dilaksanakan untuk memperbaiki proses pembelajaran matematika, diantaranya mencoba metode pembelajaran yang sifatnya baru bagi siswa. Salah satu bentuk pembelajaran yang kemungkinan besar dapat meningkatkan hasil belajar siswa adalah model pembelajaran cooperative integrated reading and composition (CIRC). Pada jenis pembelajaran ini, siswa ditekankan untuk membaca dan memahami soal yang kemudian dilanjutkan dengan mencari solusi dari soal tersebut. Dari kegiatan ini diharapkan pula siswa melakukannya untuk diri sendiri, dan dapat membantu siswa lainnya untuk lebih memahami pelajaran matematika. Penerepan model pembelajaran cooperative integrated reading and composition (CIRC) sudah berhasil dilaksanakan hal ini sesuai dengan hasil penelitian Indikhiro, dkk. (2010) yang menyatakan bahwa, "Penerapan metode pembelajaran cooperative integrated reading and composition (CIRC) berpengaruh terhadap hasil belajar peserta didik yang terlihat dari peningkatan skor rata-rata hasil belajar peserta didik sebelum dan sesudah diberi perlakuan pembelajaran dengan model cooperative integrated reading and composition (CIRC)."

\section{KAJIAN TEORI}

\section{Tinjauan Tentang Model Cooperative Integreted Reading and Composition (CIRC)}

\section{a. Model Pembelajaran Kooperatif (cooperative learning)}

Pembelajaran kooperatif adalah model pembelajaran yang dirancang untuk membelajarkan kecakapan akademik (academic skill) sekaligus keterampilan sosial (social skill) termaksud interpersonal skill (Riyanto, 2012; Syarifuddin, 2018). Pembelajaran kooperatif (Cooperative learning) merupakan bentuk pembelajaran dengan cara siswa belajar dan bekerja dalam kelompok-kelompok kecil secara kolaboratif yang anggotanya terdiri dari empat sampai enam dengan struktur kelompok yang bersifat heterogen (Rusman, 2014; Sutarto \& Syarifuddin, 2013; Wahidah, 2021).

Suprijono (2011) mengemukakan bahwa pembelajaran kooperatif adalah konsep yang lebih luas meliputi semua jenis kerja kelompok termasuk bentuk-bentuk yang lebih dipimpin oleh guru atau diarahkan oleh guru. Secara umum pembelajaran kooperatif dianggap lebih diarahkan oleh guru, di mana guru menetapkan tugas dan pertanyaan-pertanyaan serta menyediakan bahan-bahan dan informasi yang dirancang untuk membantu siswa menyelesaikan masalah yang dimaksudkan. Guru biasanya menetapkan bentuk ujian tertentu pada akhir tugas.

Dari definisi model pembelajaran kooperatif menurut beberapa para ahli diatas, penelitian dapat menyimpulkan bahwa model pembelajaran kooperatif merupakan 
model pembelajaran yang mengarahkan siswa berkelompok atau bekerja sama dalam tim guna mencapai tujuan pembelajaran yang diarahkan oleh guru.

\section{b. Model Cooperative Integreted Reading and Composition (CIRC)}

Model CIRC adalah gabungan program membaca, menulis dengan menggunakan pembelajaran baru dalam pemahaman bacaan dengan menulis, keberhasilan metode CIRC ini sangat bergantung dalam proses pembelajaran yang dilaksanakan (Azizah, 2010).

Model CIRC merupakan pembelajaran yang memberikan kesempatan siswa untuk mengekspresikan diri dalam berbicara, berpendapat, dan berkomunikasi dalam proses pembelajaran di kelas, serta memberikan kesempatan siswa untuk memahami suatu permasalahan soal dengan terlebih dahulu membaca soal dan mendiskusikannya bersama-sama (Setyaningrum, 2012). Model CIRC merupakan pembelajaran yang dapat membantu siswa untuk mengasah kemampuan pemecahan masalah dalam penyelesaian soal cerita.

Model CIRC berkembang bukan hanya dipakai pada pelajaran bahasa saja melainkan pada pelajaran matematika juga. Dalam model pembelajaran CIRC ini, siswa ditempatkan dalam kelompok kecil yang heterogen. Dalam kelompok ini tidak dibedakan atas jenis kelamin, suku, atau tingkat kecerdasan siswa (Azizah, 2010).

Jadi, peneliti dapat menyimpulkan bahwa model cooperative integrated reading composition (CIRC) adalah pembelajaran Kelompok Kecil terpadu antara membaca dan menulis. Pembelajaran tersebut memberikan kesempatan kepada siswa dalam mengekspresikan diri dalam berbicara, berpendapat, serta memberikan kesempatan siswa untuk memahami suatu permasalahan soal dengan terlebih dahulu membaca soal dan mendiskusikannya bersama-sama.

\section{c. Langkah-langkah Model Cooperative Integreted Reading and Composition (CIRC)}

Dalam mengajukan beberapa pertanyaan kepada seluruh kelas,guru menggunakan beberapa fase sebagai sintaks didapatkan fase-fase berikut:

\section{1) Fase pengenalan konsep}

Fase ini guru mulai mengenalkan tentang suatu konsep atau istilah baru yang mengacu pada hasil penemuan selama eksplorasi. Pengenalan bisa didapat dari keterangan guru, buku paket, atau media lainnya.

\section{2) Fase eksplorasi dan aplikasi}

Fase ini memberikan peluang pada siswa untuk mengungkap pengetahuan awalnya, mengembangkan pengetahuan baru, dan menjelaskan fenomena yang mereka alami dengan bimbingan guru.

\section{3) Fase publikasi}

Pada fase ini siswa mampu mengkomunikasikan hasil temuan-temuan, membuktikan, memperagakan tentang materi yang dibahas. Penemuan itu dapat bersifat sebagai sesuatu yang baru atau sekedar membuktikan hasil pengamatannya. berikut :

Adapun langkah-langkah dari Model CIRC (Azizah, 2010), yaitu sebagai

1. Membentuk kelompok yang anggotanya 4 orang yang secara heterogen.

2. Guru memberikan LKS sesuai dengan topik pembelajaran.

3. Peserta didik bekerja sama saling membacakan dan menemukan ide pokok dan memberi tanggapan terhadap LKS dan ditulis pada lembar kertas. 
4. Mempresentasikan/membacakan hasil kelompok.

5. Guru membuat kesimpulan bersama.

6. Penutup.

Jadi, adapun langkah-langkah dari model CIRC yang dilakukan oleh peneliti pada saat proses pembelajaran berlangsung sebagai berikut:

1. Membentuk kelompok yang beranggota 4-5 orang secara heterogen.

2. Membagikan LKS sesuai dengan topik pembelajaran.

3. Peserta didik bekerja sama saling membacakan dan menemukan model matematika pada soal cerita dan memberi tanggapan terhadap LKS dan ditulis pada lembar kertas.

4. Mempresentasikan/membacakan hasil kelompok.

5. Guru dan siswa membuat kesimpulan bersama-sama

6. Penutup

\section{d. Tujuan Model Pembelajaran Cooperative Integreted Reading and} Composition (CIRC)

Belajar dengan model pembelajaran kooperatif tipe CIRC merupakan belajar mandiri tanpa harus selalu mengandalkan peran guru, karena mereka telah dibagi dalam kelompok-kelompok yang memiliki kemampuan yang sama (siswa dipilih berdasarkan nilai). Dalam pembelajaran model ini guru hanya bertugas untuk memberikan bantuan pada kelompok bila kelompok tersebut belum dapat menyelesaikan tugasnya.

Tujuan penggunaan model pembelajaran kooperatif tipe CIRC adalah sebagai berikut (Slavin, 2010).

\section{Membaca Lisan}

Meningkatkan kesempatan siswa untuk membaca dengan keras dan menerima umpan balik dari kegiatan membaca, dengan membuat para siswa membaca untuk teman satu timnya dan dengan melatih mereka mengenai bagaimana saling merespon kegiatan membaca siswa.

\section{Kemampuan Memahami Bacaan}

Penggunaan tim-tim kooperatif untuk membantu siswa mempelajari kemampuan memahami bacaan yang dapat diaplikasikan secara luas.

\section{Menulis dan Seni Berbahasa}

Pengembangan CIRC terhadap pelajaran menulis dan seni berbahasa adalah untuk merancang, mengimplementasikan, dan mengevaluasi pendekatan proses menulis pada pelajaran menulis dan seni berbahasa yang akan banyak memanfaatkan kehadiran teman satu kelas.

e. Kelebihan dan kekurangan Model Pembelajaran Cooperative Integreted Reading and Composition (CIRC)

Kelebihan dari Model CIRC (Putranto, 2010), yaitu sebagai berikut :

1. Siswa dilatih untuk dapat bekerjasama dan menghargai pendapat orang lain.

2. Dalam pembelajaran, siswa dilatih memberi tanggapannya.

3. Memberikan kesempatan bagi siswa untuk mengekspresikan diri dalam membaca, berpendapat, dan berkomunikasi dalam proses pembelajaran di kelas.

4. Memberikan kesempatan bagi siswa untuk memahami suatu permasalahan soal dengan terlebih dahulu membaca soal dan mendiskusikannya bersama-sama.

Kelemahan dari Model CIRC yaitu sebagai berikut : 
1. Memerlukan waktu yang relatif lama.

2. Adanya kegiatan-kegiatan kelompok yang tidak bisa berjalan seperti apa yang diharapkan.

3. Pada saat dilakukan presentasi, terjadi kecenderungan hanya siswa pintar yang secara aktif tampil menyampaikan pendapat dan gagasan.

\section{Hasil Belajar}

Hasil belajar yaitu perubahan-perubahan yang terjadi pada diri siswa, baik yang menyangkut aspek afektif, kognitif, dan psikomotor sebagai hasil dari kegiatan belajar (Susanto, 2013; Nurwadani dkk, 2021; Susisusanti dkk, 2021). Menurut Purwanto, (2014) Hasil belajar adalah kompetensi atau kemampuan tertentu baik afektif, kognitifmaupun psikomotorik yang dicapai atau dikuasai peserta didik setelah mengikuti proses belajar mengajar. Ranah afektif mencakup watak perilaku seperti perasaan, minat, sikap, emosi, atau nilai. Kemampuan afektif berhubungan dengan minat dan sikap yang dapat berbentuk tanggung jawab, kerja sama, disiplin, komitmen, percaya diri, jujur, menghargai pendapat orang lain, dan kemampuan mengendalikan diri Ranah kognitif adalah pencapaian atau penguasaan peserta didik dalam aspek pengetahuan yang meliputi ingatan atau hafalan, pemahaman, penerapan atau aplikasi, analisis, sintesis, dan evaluasi (Purwanto, 2014; Sartika, 2020). Ranah psikomotor berkenaan dengan ketrampilan atau kemampuan bertindak setelah ia menerima pengalaman belajar tertentu (Purwanto, 2014). Secara sederhana, yang dimaksud dengan hasil belajar siswa adalah kemampuan yang diperoleh anak setelah melalui kegiatan belajar (Susanto, 2013; Silviana, 2021; Murtalib, 2021).

Dari definisi hasil belajar menurut para ahli diatas, peneliti dapat menyimpulkan bahwa hasil belajar adalah suatu perubahan yang terjadi pada diri siswa yang menyangkut tiga aspek yaitu aspek kognitif seperti pencapaian atau penguasaan peserta didik, aspek afektif seperti perasaan, minat, sikap, emosi, atau nilai. , dan aspek psikomotor seperti keterampilan siswa setelah melalui kegiatan belajar.

\section{METODE PENELITIAN}

Jenis penelitian yang digunakan adalah penelitian kuantitatif dengan metode eksperimen karena penelitian ini diberikan suatu perlakuan (treatment) untuk mengetahui hubungan antara perlakuan tersebut dengan aspek tertentu yang akan diukur. Desain eksperimen dalam penelitian ini adalah Quasi Experimental Design yaitu suatu metode penelitian berupa eksperimen semu dimana menggunakan rancangan penelitian yang tidak dapat mengontrol secara penuh kondisi penelitian. Metode ini hanya memungkinkan penelitian dengan kondisi yang sudah ada. Untuk pelaksanaan diperlukan dua kelas. Kelas eksperimen diberikan perlakuan (X) yaitu pembelajaran matematika dengan menggunakan model pembelajaran Cooperative Integrated Reading Composition (CIRC), kelas kontrol diberikan pembelajaran dengan metode konvensional. Kelas yang diberikan perlakuan disebut kelas eksperimen dan kelas yang tidak diberikan perlakuan disebut kelas kontrol.

\section{HASIL DAN PEMBAHASAN}

\section{Hasil Penelitian}

@ 2022 DIKSI (https://jurnal.bimaberilmu.com/index.php/diksi) 
Hasil Uji Normalitas dan Homogenitas

a. Uji Normalitas Prettest Kedua Kelas

Tabel 2. Hasil Perhitungan Uji Normalitas Prettest Kedua Kelas

\begin{tabular}{cccccc}
\hline No & Kelas & $\begin{array}{c}\text { Jumlah Nilai } \\
\text { Prettest }\end{array}$ & $\mathrm{X}^{2}{ }_{\text {hitung }}$ & $\mathrm{X}^{2}$ tabel & Kesimpulan \\
\hline 1 & Eksperimen & 825 & 4,571 & 11,070 & Normal \\
\hline 2 & Kontrol & 725 & 7,385 & 12,592 & Normal \\
\hline
\end{tabular}

Berdasarkan hasil perhitungan untuk uji normalitas yang diambil dari nilai prettest dari kedua sampel untuk di uji, untuk kelas eksperimen diperoleh $x^{2}{ }_{h i t u n g}=$ 4,571 dan dari tabel distribusi diperoleh $x^{2}$ tabel $=11,070$ dan untuk kelas kontrol $x_{\text {hitung }}^{2}=7,385$ dan dari tabel distribusi diperoleh $x_{\text {tabel }}^{2}=12,592$ pada taraf signifikan 5\%. Berdasarkan kriteria pengujian jika $x^{2}{ }_{\text {hitung }}<x_{\text {tabel }}^{2}$ maka data tersebut Normal.

\section{b. Uji Homogenitas Varians Prettest Kedua Sampel}

Tabel 3 Hasil Perhitungan Uji Homogenitas Prettest Kedua Kelas

\begin{tabular}{ccccc}
\hline No & Kelas & $\mathrm{F}_{\text {hitung }}$ & $\mathrm{F}_{\text {tabel }}$ & Kesimpulan \\
\hline 1 & Eksperimen & 1,454762 & 4,026631 & Homogen \\
\hline 2 & Kontrol & & & \\
\hline
\end{tabular}

Berdasarkan hasil perhitungan untuk uji homogenitas yang diambil dari nilai Prettest dari kedua sampel untuk diuji, diperoleh $F_{\text {hitung }}=1,454762$ dan dari tabel distribusi $\mathrm{F}$ diperoleh $\mathrm{F}_{\text {tabel }}=4,026631$ pada taraf signifikan 5\%. Berdasarkan Kriteria pengujian jika $F_{\text {hitung }} \leq F_{\text {tabel }}$ maka tabel Homogen. Dengan demikian dapat dikatakan bahwa kedua sampel yaitu kelas eksperimen dan kelas kontrol memiliki kemampuan yang homogen.

\section{Hasil Uji Hipotesis (Uji-t)}

Data hasil uji hipotesis dijelaskan pada tabel distribusi frekuensi berikut ini:

Tabel 4. Hasil Perhitungan Uji Hipotesis Posttest Kedua Kelas

\begin{tabular}{clcccc}
\hline No & Kelas & $\mathrm{t}_{\text {hitung }}$ & $\mathrm{t}_{\text {tabel }}$ & $\mathrm{Dk}=\mathrm{n}_{1}+\mathrm{n}_{2}-2$ & Kesimpulan \\
\cline { 1 - 4 } 1 & Eksperimen & 4,326 & 1,988 & 52 & Ha diterima \\
\cline { 1 - 2 } 2 & Kontrol & & & & \\
\hline
\end{tabular}

Harga $t_{\text {hitung }}$ tersebut dibandingkan dengan harga $t_{\text {tabel }}$ pada taraf signifikan 5\% untuk uji dua pihak dengan $\mathrm{Dk}=\mathrm{n}_{1}+\mathrm{n}_{2}-2=52$ harga $\mathrm{t}_{\text {tabel }}=1,988$. Karena harga $t_{\text {hitung }} \geq \mathrm{t}_{\text {tabel }}$ atau 4,326 $\geq 1,988$ sehingga Ho ditolak dan Ha diterima. Jadi dapat disimpulkan bahwa penggunaan model cooperative integrated reading composition (CIRC) berpengaruh terhadap hasil belajar siswa pada materi sistem persamaan linear dua variabel (SPLDV) kelas VIII MTsN 4 Bima tahun pelajaran 2019/2020.

\section{Data Hasil Belajar Kelas Eksperimen}

Jumlah siswa kelas eksperimen pada penyelesaian soal prettest sebanyak 28 orang dan penyelesaian pada soal posttest sebanyak 21 orang.

Tabel 5. Data Prettest Posttest -rata, $\mathrm{X}_{\min }, \mathrm{X}_{\max }$, dan Nilai Varians kelas eksperimen

\begin{tabular}{ccccccc}
\hline No & Jenis Test & Jumlah & $\bar{x}$ & $\mathrm{X}_{\min }$ & $\mathrm{X}_{\max }$ & $s^{2}$ \\
\hline 1 & Prettest & 825 & 29,46429 & 15 & 40 & 52,480159 \\
\hline 2 & Posttest & 2050 & 73,21429 & 50 & 95 & 105,95238 \\
\hline
\end{tabular}


Pada tabel diatas terdapat dua jenis test,yaitu prettest dan posttest. Jenis test prettest dengan jumlah nilai 825 dari keseluruhan siswa, nilai rata-rata ( $\bar{x})$ diperoleh 29,46429 , nilai minimum $\left(X_{\min }\right)$ adalah 15 , nilai maksimum $\left(\mathrm{X}_{\max }\right)$ adalah 40 dan nilai varians $\mathrm{s}^{2}$ ) pada pretest 52,480159 .

Sedangkan posttest dengan jumlah nilai 2050 dari keseluruhan siswa, nilai rata$\operatorname{rata}(\bar{x})$ diperoleh 73,21429 , nilai minimum $\left(X_{\min }\right)$ adalah 50, nilai maksimum $\left(X_{\max }\right)$ adalah 90 dan nilai varians $\left(s^{2}\right)$ pada prettest 105,95238 . Jadi dapat disimpulkan bahwa dari kedua data antara prettest dan posttest memiliki tingkat perbedaan sebelum diajarkan dan sesudah diajarkan dengan menggunakan model CIRC

Dari tabel dan uraian diatas nilai prettest dan posttest kelas eksperimen dapat didistribusikan pada kedua tabel sebagai berikut:

Tabel 6 Distribusi Nilai Prettest Kelas Eksperimen

\begin{tabular}{cccc}
\hline No & Kelas Interval & $\mathrm{f}_{\mathrm{o}}$ & Persentase \\
\hline 1 & $15-19$ & 1 & $3,57 \%$ \\
2 & $20-24$ & 5 & $17,85 \%$ \\
3 & $25-29$ & 5 & $17,85 \%$ \\
4 & $30-34$ & 6 & $21,42 \%$ \\
5 & $35-39$ & 7 & $25 \%$ \\
6 & $40-44$ & 4 & $14,28 \%$ \\
& Jumlah & 28 & $100 \%$ \\
\hline
\end{tabular}

Pada tabel distribusi frekuensi nilai prettest yaitu sebelum diberi perlakuan diatas bahwa siswa yang mendapatkan nilai terendah sampai tertinggi sejumlah 28 siswa dengan nilai terendah 15-19 sebanyak 1 siswa dan mendapatkan persentase $3,57 \%$, nilai 20-29 sebanyak 10 siswa dan mendapatkan persentase $17,85 \%$, nilai 30 34 sebanyak 6 siswa dan mendapatkan persentase 21,42\%, nilai 35-39 sebanyak 7 siswa dan mendapatkan persentase 25\% dan nilai 40-44 sebanyak 4 siswa dan mendapatkan persentase 14,28. Jadi dapat disimpulkan bahwa mayoritas besarnya persentase yang ada pada tabel dan uraian diatas adalah $25 \%$ dengan mendapatkan nilai 35-39 sebanyak 7 siswa dari total keseluruhan siswa.

Tabel 7. Distribusi Nilai Posttest Kelas Eksperimen

\begin{tabular}{cccc}
\hline No & Kelas Interval & $\mathrm{f}_{\mathrm{o}}$ & Persentase \\
\hline 1 & $46-50$ & 1 & $3,57 \%$ \\
2 & $51-55$ & 0 & $0 \%$ \\
3 & $56-60$ & 4 & $14,28 \%$ \\
4 & $61-65$ & 2 & $7,14 \%$ \\
5 & $66-70$ & 5 & $17,85 \%$ \\
6 & $71-75$ & 8 & $28,57 \%$ \\
7 & $76-80$ & 4 & $14,28 \%$ \\
8 & $81-85$ & 2 & $7,14 \%$ \\
9 & $86-90$ & 0 & $0 \%$ \\
10 & $91-95$ & 2 & $7,14 \%$ \\
& Jumlah & 28 & $100 \%$ \\
\hline
\end{tabular}

Dari table distribusi frekuensi posttest yaitu setelah diberikan perlakuan dengan menggunakan model cooperative integrated reading composition (CIRC) 
mendapatkan nilai terendah sampai nilai tertinggi. Dengan nilai terendah 46-50 sebanyak 1 siswa dan mendapatkan persentase 3,57\%, nilai 51-55 sebanyak 0 siswa dan mendapatkan persentase 0\%, nilai 56-60 sebanyak 4 siswa dan mendapatkan persentase $14,28 \%$, nilai $61-65$ sebanyak 2 siswa dan mendapatkan persentase $7,14 \%$, nilai $66-70$ sebanyak 5 siswa dan mendapatkan persentase $17,85 \%$, nilai 71 75 sebanyak 8 siswa dan mendapatkan persentase 28,57\%, nilai 76-80 sebanyak 4 siswa dan mendapatkan persentase 14,28\%, nilai 81-85 sebanyak 2 siswa dan mendapatkan persentase $7,14 \%$, nilai $86-90$ sebanyak 0 siswa dan mendapatkan persentase 0\%, dan nilai 91-95 sebanyak 2 siswa dan mendapatkan persentase $7,14 \%$. Jadi dapat disimpulkan bahwa mayoritas besarnya persentase yang ada pada tabel dan uraian diatas adalah 28\% dengan mendapatkan nilai 71-75 sebanyak 8 siswa dari total keseluruhan siswa.

\section{Data Hasil Belajar Kelas Kontrol}

Jumlah siswa kelas kontrol pada penyelesaian soal prettest sebanyak 26 orang dan penyelesaian pada soal posttest sebanyak 26 orang

Tabel 8. Data Prettest Posttest nilai rata-rata, $\mathrm{X}_{\min }, \mathrm{X}_{\max }$, Nilai Varians kelas kontrol

\begin{tabular}{rrrcrrc}
\hline No & Jenis Test & Jumlah & $\bar{x}$ & $X_{\min }$ & $X_{\max }$ & $s^{2}$ \\
\hline 1 & Prettest & 725 & 27,8846 & 10 & 40 & 76,346154 \\
2 & posttest & 1500 & 57,69231 & 30 & 90 & 246,461538 \\
\hline
\end{tabular}

Pada tabel diatas terdapat dua jenis test,yaitu prettest dan posttest. Jenis test prettest dengan jumlah nilai 725 dari keseluruhan siswa, nilai rata-rata ( $\bar{x})$ diperoleh 27,8846 , nilai minimum $\left(\mathrm{X}_{\min }\right)$ adalah 10 , nilai maksimum $\left(\mathrm{X}_{\max }\right)$ adalah 40 dan nilai varians $S^{2}$ ) pada pretest 76,346154 .

Sedangkan posttest dengan jumlah nilai 1500 dari keseluruhan siswa, nilai rata$\operatorname{rata}(\bar{x})$ diperoleh 57,69231, nilai minimum $\left(\mathrm{X}_{\min }\right)$ adalah 30, nilai maksimum $\left(\mathrm{X}_{\max }\right)$ adalah 90 dan nilai varians $\left(s^{2}\right)$ pada prettest 246,461538. Jadi dapat disimpulkan bahwa dari kedua data antara prettest dan posttest memiliki tingkat perbedaan sebelum diajarkan dan sesudah diajarkan dengan menggunakan model konvensional.

Dari tabel di atas nilai prettest dan posttest kelas kontrol dapat didistribusikan pada kedua tabel sebagai berikut:

Tabel 9. Distribusi Nilai Prettest Kelas Kontrol

\begin{tabular}{cccc}
\hline No & Kelas Interval & $\mathrm{f}_{\mathrm{o}}$ & Persentase \\
\hline 1 & $10-14$ & 1 & $3,84 \%$ \\
2 & $15-19$ & 1 & $3,84 \%$ \\
3 & $20-24$ & 7 & $26,92 \%$ \\
4 & $25-29$ & 4 & $15,38 \%$ \\
5 & $30-34$ & 4 & $15,38 \%$ \\
6 & $35-39$ & 4 & $15,38 \%$ \\
7 & $40-44$ & 5 & $19,23 \%$ \\
& Jumlah & 26 & $100 \%$ \\
\hline
\end{tabular}

Pada tabel distribusi frekuensi nilai prettest yaitu sebelum diberi perlakuan diatas bahwa siswa yang mendapatkan nilai terendah sampai tertinggi sejumlah 26 siswa dengan nilai terendah 10-14 sebanyak 1 siswa dan mendapatkan persentase $3,84 \%$, nilai 15-19 sebanyak 1 siswa dan mendapatkan persentase 3,84\%, nilai $20-24$ sebanyak 7 siswa dan mendapatkan persentase $26,92 \%$, nilai $25-29$ sebanyak 4 siswa 
dan mendapatkan persentase 15,38\%, nilai 30-34 sebanyak 4 siswa dan mendapatkan persentase $15,38 \%$, nilai $35-39$ sebanyak 4 siswa dan mendapatkan persentase $15,38 \%$ dan nilai 40-44 sebanyak 5 siswa dengan mendapatkan persentase $19,23 \%$. Jadi dapat disimpulkan bahwa mayoritas besarnya persentase yang ada pada tabel dan uraian diatas adalah $26,92 \%$ dengan mendapatkan nilai 20-24 sebanyak 7 siswa dari total keseluruhan siswa.

Tabel 10. Distribusi Nilai Posttest Kelas Kontrol

\begin{tabular}{cccc}
\hline No & Kelas Interval & $\mathrm{f}_{\mathrm{o}}$ & Persentase \\
\hline 1 & $30-34$ & 2 & $7.69 \%$ \\
2 & $35-39$ & 1 & $3,84 \%$ \\
3 & $40-44$ & 2 & $7.69 \%$ \\
4 & $45-49$ & 0 & $0 \%$ \\
5 & $50-54$ & 4 & $15,38 \%$ \\
6 & $55-59$ & 4 & $15,38 \%$ \\
7 & $60-64$ & 4 & $15,38 \%$ \\
8 & $65-69$ & 3 & $11,53 \%$ \\
9 & $70-74$ & 3 & $11,53 \%$ \\
10 & $75-79$ & 0 & $0 \%$ \\
11 & $80-84$ & 1 & $3,84 \%$ \\
12 & $85-89$ & 0 & $0 \%$ \\
13 & $90-94$ & 2 & $7,69 \%$ \\
& Jumlah & 26 & $100 \%$ \\
\hline
\end{tabular}

Dari table distribusi frekuensi posttest yaitu setelah diberikan perlakuan dengan menggunakan model kovensional mendapatkan nilai terendah sampai nilai tertinggi. Dengan nilai terendah 30-34 sebanyak 2 siswa dan mendapatkan persentase 7,69\%, nilai 35-39 sebanyak 1 siswa dan mendapatkan persentase 3,84\%, nilai 40-44 sebanyak 2 siswa dan mendapatkan persentase 7,69\%, nilai 45-49 sebanyak 0 siswa dan mendapatkan persentase 0\%, nilai 50-54 sebanyak 4 siswa dan mendapatkan persentase $15,38 \%$, nilai $55-59$ sebanyak 4 siswa dan mendapatkan persentase $15,38 \%$, nilai $60-64$ sebanyak 4 siswa dan mendapatkan persentase $15,38 \%$, nilai 65 69 sebanyak 3 siswa dan mendapatkan persentase 11,53\%, nilai 70-74 sebanyak 3 siswa dan mendapatkan persentase $11,53 \%$, nilai 75-79 sebanyak 0 siswa dan mendapatkan persentase $0 \%$, nilai $80-84$ sebanyak 1 siswa dan mendapatkan persentase $3,84 \%$, nilai $85-89$ sebanyak 0 siswa dan mendapatkan persentase $0 \%$, dan nilai 90-94 sebanyak 2 siswa dan mendapatkan persentase 7,69\%, Jadi dapat disimpulkan bahwa mayoritas besarnya persentase yang ada pada tabel dan uraian diatas adalah 15,38\% dengan mendapatkan nilai 50-64 sebanyak 12 siswa dari total keseluruhan siswa.

\section{PEMBAHASAN}

Model cooperative integrated reading composition (CIRC) merupakan model pembelajaran kooperative terpadu membaca,menulis dimana siswa dibuat kelompok yang dibagi secara heterogen guna saling bekerja sama, dapat mengekspresikan diri dalam berbicara, berpendapat, dan berkomunikasi dalam proses pembelajaran di kelas, serta memberikan kesempatan siswa untuk memahami suatu permasalahan soal dengan terlebih dahulu membaca soal dan mendiskusikannya bersama-sama. 
Model pembelajaran cooperative integrated reading composition (CIRC) dalam penelitian ini dapat meningkatkan hasil belajar siswa pada materi sistem persamaan linear dua variabel (SPLDV) pada kelas VIII MTsN 4 Bima.

Penelitian ini dilaksanakan sesuai dengan prosedur penelitian eksperimen yang telah ditetapkan sebelumnya diawali dengan tahap persiapan, tahap pelaksanaan pembelajaran, dan tahap melakukan evaluasi. Penelitian ini tidak hanya penelitian kelas eksperimen tetapi menggunakan kelas kontrol sebagai garis dasar untuk dibandingkan dengan kelas yang dikenai eksperimen. Kelas eksperimen yang diberi perlakuan dengan pemberian model pembelajaran cooperative integrated reading composition (CIRC) sedangkan kelas kontrol diberi perlakuan berupa proses pembelajaran dengan menggunakan metode konvensional (ceramah, tanya jawab, diskusi dan pemberian tugas).

Penerapan Model pembelajaran cooperative integrated reading composition (CIRC) sudah berhasil dilaksanakan hal ini sesuai dengan hasil penelitian indikhiro,dkk.(2010) yang menyatakan bahwa," penerapan metode pembelajaran cooperative integrated reading composition (CIRC) berpengaruh terhadap hasil belajar terlihat dari peningkatan skor rata-rata hasil belajar peserta didik sebelum dan sesudah diberi perlakuan pembelajaran dengan model cooperative integrated reading composition (CIRC)". Sedangkan dari hasil peneliti didapatkan nilai rata-rata siswa pada kelas eksperimen yang dicapai 71-75 dengan persentase $28,57 \%$ dan hasil penelitian analisis statistik diperoleh nilai $t_{\text {hitung }}=4,326$ pada taraf signifikansi $5 \%$ sedangkan $\mathrm{t}_{\text {tabel }}=1,988$ pada taraf signifikan $5 \%$ yang berarti $t_{\text {hitung }} \geq \mathrm{t}_{\text {tabel. }}$. Dengan demikian hasil belajar siswa pada materi sistem persamaan linear dua variabel (SPLDV) yang diajarkan dengan menggunakan model cooperative integrated reading composition (CIRC) berpengaruh pada siswa kelas VIII MTsN 4 Bima.

Dalam penelitian ini, ada atau tidaknya pengaruh hasil belajar siswa dapat dilihat dari hasil hipotesis (uji-t). Dari hasil perhitungan diperoleh nilai $t_{\text {hitung }} \geq t_{\text {tabel }}$ yang berarti hipotesis nol (Ho) ditolak dan Hipotesis alternatif (Ha) yang berbunyi penggunaan model cooperative integrated reading composition (CIRC) berpengaruh pada siswa kelas VIII MTsN 4 Bima diterima. Hal ini menunjukkan bahwa pembelajaran dengan menggunakan model pembelajaran cooperative integrated reading composition (CIRC) berpengaruh sehingga berhasil dalam meningkatkan hasil belajar siswa kelas VIII MTsN 4 Bima.

Kelebihan dari penggunaan model cooperative integrated reading composition (CIRC) adalah siswa dilatih untuk dapat bekerjasama dan menghargai pendapat orang lain,memberi tanggapannya, memberikan kesempatan bagi siswa untuk mengekspresikan diri dalam membaca, berpendapat, dan berkomunikasi dalam proses pembelajaran di kelas dan memberikan kesempatan bagi siswa untuk memahami suatu permasalahan soal dengan terlebih dahulu membaca soal dan mendiskusikannya bersama-sama. Dengan demikian dapat disimpulkan bahwa model pembelajaran adalah strategi/cara yang dipilih guru berupa tahap-tahap kegiatan belajar khususnya penyajian materi dalam rangka membantu siswa mencapai tujuan pembelajaran yang baik.

Pembelajaran matematika bertujuan untuk meningkatkan keterampilan siswa, mengantar siswa menemukan dan mengatur sendiri pengetahuannya bukan mentransfernya saja. Untuk mencapai tujuan tersebut diperlukan model pembelajaran yang benar-benar tepat. Oleh karna itu, salah satu model yang sesuai dengan tujuan 
pembelajaran yaitu model pembelajaran kooperatife tipe cooperative integrated reading composition (CIRC).

Berdasarkan uraian diatas dapat disimpulkan bahwa penggunaan model pembelajaran cooperative integrated reading composition (CIRC) berpengaruh terhadap hasil belajar siswa pada materi sistem persamaan linear dua variabel (SPLDV) pada kelas VIII MTsN 4 Bima tahun pelajaran 2020/2021.

\section{KESIMPULAN}

Berdasarkan data hasil penelitian dan pembahasan yang diuraikan sebelumnya dapat disimpulkan bahwa model cooperative intagrated reading composition (CIRC) berpengaruh terhadap hasil belajar siswa pada materi sistem persamaan linear dua variabel (SPLDV) kelas VIII MTsN 4 Bima tahun pelajaran 2020/2021. Hal ini sesuai dengan Hasil Uji hipotesis dimana, nilai $t_{\text {hitung }}>t_{\text {tabel }}$ yaitu $t_{\text {hitung }}=4,326$ dan $t_{\text {tabel }}=1,988$ dengan taraf signifikansi $5 \%$ dan taraf kepercayaan $95 \%$.

\section{DAFTAR PUSTAKA}

Azizah. (2010). Pengaruh pembelajaran CIRC (cooperative integreted reading and composition) Terhadap Kemampuan Menyelesaikan Soal Cerita Matematika. Jurusan Pendidikan Matematika Fakultas Ilmu Tarbiyah Dan Keguruan Universitas Negeri Syarif Hidayatullah Jakarta 1432 H/2010 M. (4 mei 2019).

Indikhiro dkk. (2010). Penerapan Model Pembelajaran Coopertive integrated reading and composition (CIRC) berbasis computer untuk meningkatkan hasil belajar siswa pada pembelajaran TIK. Jurnal pendidikan teknologi informasi dan komunikasi (PTIK) Vol. 3 No. 1/Juni 2010

Murtalib, M., Dusalan, D., Marweli, M., \& Rohana, R. (2021). Penerapan Pendekatan Kontekstual pada Materi Pokok Trigonometri untuk Meningkatkan Prestasi Belajar Siswa. Jurnal Pendidikan dan Pembelajaran Indonesia (JPPI), 1(1), 22-29.

Nurwadani, P. A., Syarifuddin, S., Gunawan, G., \& Dusalan, D. (2021). Hubungan Model Pembelajaran Kooperatif Tipe Numbered Head Together (NHT) terhadap Minat dan Hasil Belajar Siswa di Kelas VII SMP Negeri 4 Kota Bima Tahun Pelajaran 2021/2022. DIKSI: Jurnal Kajian Pendidikan dan Sosial, 2(1), 25-38.

Purwanto. (2014). Evaluasi Hasil Belajar. Yogyakarta: Pustaka Pelajar

Putranto, Eko Puji. (2010). Penerapan Model Pembelajaran Kooperatif Tipe CIRC Berbantuan Modul Untuk Meningkatkan Keaktivan dan Hasil Belajar Siswa Kelas VIIIA mts N 1 Gemolong Tahun Ajaran 2009/2010. Online. Tersedia di http://eprints.uns.ac.id

Riyanto, Y. (2012). Paradigma Baru Guru/Pendidikan dalam Implementasi Pembelajaran yang Efektif dan Berkualitas. Jakarta: Kencana.

Rusman. (2014). Metode-Metode Pembelajaran: Mengembangkan Profesionalisme Guru. Jakarta: PT RajaGrafindo Persada

Sartika, D., Baeti, N., Saifullah, S., Tunisah, A., \& Furahman, R. (2020). Pembelajaran Berbasis Kontekstual dalam Meningkatkan Aktivitas dan Prestasi 
Belajar Siswa pada Materi Pokok Segitiga di Kelas VII SMP Negeri 2 Bolo Tahun 2019/2020. DIKSI: Jurnal Kajian Pendidikan dan Sosial, 1(2), 107-122.

Setyaningrum. (2012). Keefektifan Model Pembelajaran Kooperatif Tipe CIRC dan

NHT Dengan Pemodelan Matematika Dalam Menyelesaikan Soal Cerita Kelas

VIII. Jurnal Artikel, (Online), (http://journal.unnes.ac.id/sju/

Silviana, D., Mikrayanti, M., Jauhari, R. S., \& Furqan, M. (2021). Penerapan Realistic Mathematics Education untuk Meningkatkan Aktivitas dan Hasil Belajar Siswa Sekolah Menengah Pertama pada Materi Pokok Fungsi. JagoMIPA: Jurnal Pendidikan Matematika dan IPA, 1(1), 21-35.

Slavin. (2010). Cooperative Learning: theory, research and practice (Buku Cooperative Learning: Teori, Riset dan Praktek). Penerjemah: Narulita Yusron. Bandung: Nusa Media.

Suprijono. (2011). Model-Model Pembelajaran. Jakarta: Gramedia Pustaka Jaya

Susanto, S. (2013). Teori Belajar \& Pembelajaran. Jakarta: Prenada Media Grup.

Susisusanti, S., Wirahmad, I., \& Syarifuddin, S. (2021). Penerapan Metode Pembelajaran EPA (Eksplorasi, Pengenalan, dan Aplikasi Konsep) dalam Meningkatkan Hasil Belajar Siswa SMP Negeri 8 Donggo Satap Materi Operasi Bilangan Pecahan. DIKSI: Jurnal Kajian Pendidikan dan Sosial, 2(2), 86-105.

Sutarto, S., Pd, M., Syarifuddin, S. P., \& Pd, M. (2013). Desain Pembelajaran Matematika. Yogyakarta: Samudra Biru.

Syarifuddin, S. (2018). Pengaruh Pembelajaran Kooperatif Tipe Jigsaw Dan Tipe Group Investigation (GI) Terhadap Ketercapaian Kompetensi Dan Kemampuan Komunikasi Matematika Siswa Di SMA. Jurnal Ilmiah Mandala Education, 4(1), 163-172.

Wahidah, W. (2021). Penerapan Model Pembelajaran Kooperatif Tipe Jigsaw untuk Meningkatkan Aktivitas dan Prestasi Belajar Fisika Siswa SMP. JagoMIPA: Jurnal Pendidikan Matematika dan IPA, 1(1), 9-20. 